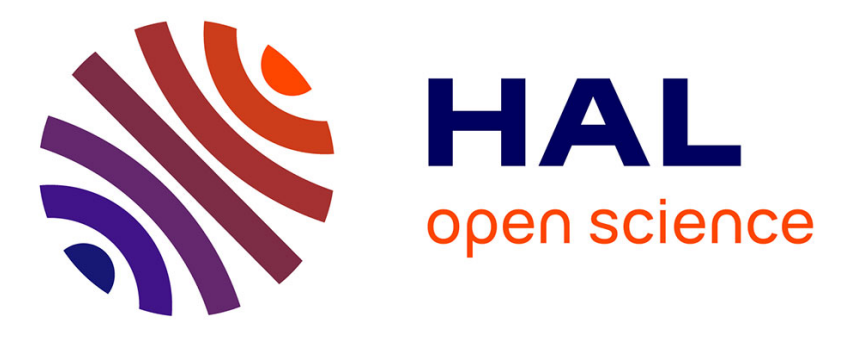

\title{
A Deficit of Brain Dystrophin 71 Impairs Hypothalamic Osmostat
}

\author{
Roza Benabdesselam, Abdoulaye Sene, Danièle Raison, Ouahiba \\ Benmessaoud-Mesbah, Ghazi Ayad, Dominique Mornet, David Yaffe, Alvaro \\ Rendon, Hélène Hardin-Pouzet, Latifa Dorbani-Mamine
}

\section{To cite this version:}

Roza Benabdesselam, Abdoulaye Sene, Danièle Raison, Ouahiba Benmessaoud-Mesbah, Ghazi Ayad, et al.. A Deficit of Brain Dystrophin 71 Impairs Hypothalamic Osmostat. Journal of Neuroscience Research, 2010, 10.1002/jnr.22198 . hal-02547042

\section{HAL Id: hal-02547042 \\ https://hal.umontpellier.fr/hal-02547042}

Submitted on 19 Apr 2020

HAL is a multi-disciplinary open access archive for the deposit and dissemination of scientific research documents, whether they are published or not. The documents may come from teaching and research institutions in France or abroad, or from public or private research centers.
L'archive ouverte pluridisciplinaire HAL, est destinée au dépôt et à la diffusion de documents scientifiques de niveau recherche, publiés ou non, émanant des établissements d'enseignement et de recherche français ou étrangers, des laboratoires publics ou privés. 


\title{
A Deficit of Brain Dystrophin 71 Impairs Hypothalamic Osmostat
}

\author{
Roza Benabdesselam, ${ }^{1,2}$ Abdoulaye Sene, ${ }^{3}$ Danièle Raison, ${ }^{4}$ \\ Ouahiba Benmessaoud-Mesbah, ${ }^{1}$ Ghazi Ayad, ${ }^{2}$ Dominique Mornet, ${ }^{5}$ David Yaffe, \\ Alvaro Rendon, ${ }^{3}$ Hélène Hardin-Pouzet, ${ }^{4 \star}$ and Latifa Dorbani-Mamine ${ }^{2}$ \\ ${ }^{1}$ Unité de Recherches, Faculté des Sciences Biologiques/UMMTO, BP 17, Tizi-Ouzou, Algérie \\ ${ }^{2}$ Laboratoire de Neurochimie/LBPO, FSB/USTHB, BP 32, El Alia, Bab Ezzouar, Alger, Algérie \\ ${ }^{3}$ INSERM UMR S 592 Laboratoire de Physiopathologie Cellulaire et Moléculaire de la Rétine, \\ Institut de la Vision, Paris, France \\ ${ }^{4}$ Université Pierre et Marie Curie, Paris VI, INSERM UMRS 952, CNRS UMR 7224, \\ Physiopathologie des Maladies du Système Nerveux Central, Bât A, 3ème étage, Paris, France \\ ${ }^{5}$ INSERM ERI 25 Université de Monpellier 1, EA 4202, CHU Arnaud de Villeneuve, \\ Monpellier, France \\ ${ }^{6}$ Department of Molecular Cell Biology, Weizmann Institute of Science, Rehovot, Israel
}

Patients with Duchenne muscular dystrophy (DMD) and $m d x$ mice, devoid of dystrophin proteins, show altered ionic homeostasis. To clarify dystrophin's involvement in the central control of osmotic stimuli, we investigated the effect of the disruption of Dp71, the major form of dystrophin in the brain, on the hypothalamoneurohypophysis system (HNHS) osmoregulatory response. Dp71 and Dp140 are the principal DMD gene products in the supraoptic nucleus (SON) and neurohypophysis $(\mathrm{NH})$. They are present in astrocyte and pituicyte end-feet, suggesting involvement in both intrinsic osmosensitivity of the SON and vasopressin (AVP) release from the $\mathrm{NH}$. In Dp71-null mice, the cellular distribution of Dp140 was modified, this protein being detected on the membrane of magnocellular soma. The plasma osmolality of Dp71-null mice was lower than that of wild-type mice under normal conditions, and this difference was maintained after salt loading, indicating a change in the set point for osmoregulation in the absence of Dp71. The increase in AVP levels detected in the SON and $\mathrm{NH}$ of the wild-type was not observed in Dp71-null mice following salt loading, and the increase in AVP mRNA levels in the SON was smaller in Dp71-null than in wild-type mice. This suggests that Dp71 may be involved in the functional activity of the HNHS. Its astrocyte end-feet localization emphasizes the importance of neuronal-vascular-glial interactions for the central detection of osmolality. In the SON, Dp71 may be involved in osmosensitivity and definition of the "osmostat," whereas, in the neurohypopohysis, it may be involved in fine-tuning AVP release.

Key words: Dp71; supraoptic nucleus; neurohypophysis; vasopressin; osmoregulation

Dystrophin, the largest product of the Duchenne muscular dystrophy (DMD) gene, was first identified as a $427-\mathrm{kDa}$ protein in muscle, mediating interactions between actin filaments and the extracellular matrix. These interactions involve the dystrophin-associated protein complex (DAPC), consisting of a multiple protein scaffold (the dystrophin glycoprotein complex; DGC) and cytoplasmic factors (Matsumara and Campbell, 1994). The DMD gene has internal promoters driving the production of four proteins: Dp260, Dp140, Dp116, and Dp71. The Dp71 protein is the major form of dystrophin in brain (Austin et al., 2000). Dp71 has been detected in cultured astrocytes (Imamura and Ozawa, 1998) and neurons (Gorecki and Barnard, 1995) but is found principally in brain vessels (Loufrani et al., 2001; Haenggi et al., 2004). The association of Dp71 with components of the DGC has provided evidence for the involvement of Dp71 in brain development, synapse formation, and cerebral plasticity (Haenggi and Fritschy, 2006). In the retina, Dp71 is essential for the ionic homeostasis because of its role in the clustering of Kir $4.1 \mathrm{~K}^{+}$channels and AQP4 aqueous pores (Dalloz et al., 2003; Fort et al., 2008). Moreover, analysis of DMD patients or $m d x$ mice, mutant for dystrophin proteins, showed abnormal metabolic profiles in muscles, plasma, and brain, with perturbations in creatine, taurine, and atrial natriuretic peptide levels, leading to an altered ionic buffering and osmotic imbalance (Yanagisawa et al.,

The last two authors contributed equally to this work.

*Correspondence to: Hélène Hardin-Pouzet, Physiopathologie des Maladies du Système Nerveux Central, INSERM UMRS 592, CNRS UMR 7522, Université Pierre et Marie Curie, Paris VI, 7 quai Saint Bernard, Bât A, 3ème étage, 75252 Paris Cedex 05, France.

E-mail: helene.pouzet@snv.jussieu.fr 
1990; Stuhrmann et al., 1991; Brazeau et al., 1992; Griffin et al., 2001, 2002; Rae et al., 2002).

Osmotic homeostasis is maintained principally by the neurohormone arginine vasopressin (AVP), which is synthesized in the magnocellular neurons (MCNs) of the supraoptic (SON) and paraventricular nuclei of the hypothalamoneurohypophysis system (HNHS), transported via the axons, and released into the neurohypophysis $(\mathrm{NH})$ by the electrical activity of the MCNs, which are themselves subject to both excitatory and inhibitory inputs (Bourque, 1998). Hyperosmolality can be detected directly, through the intrinsic osmosensitivity of MCNs, and indirectly, via the specialized osmoreceptive neurons of the circumventricular organs (Zhang and Bourque 2003; McKinley et al., 2004). Fine-tuning of the amount of AVP released, to normalize plasmatic osmolality, is accompanied by a process known as "function-related plasticity" occurring both at the SON and at the NH levels (Hatton, 1997). This plasticity is governed by complex, dynamic interplay between the intrinsic properties of the MCNs, their interactions with each other and with glia, and the influence of extrinsic synaptic inputs (Ghorbel et al., 2006). This involves remodelling of the extracellular matrix and activation of receptors or intracytoplasmic metabolic pathways (Sheng and Wyszynski, 1997). Because dystrophins are associated with components of the DGC and, therefore, with various membrane factors, including receptors, signaling enzymes, and the extracellular matrix (Dalloz et al., 2003; Fort et al., 2008), these proteins, and Dp71 in particular, may play a major role in the reception and integration of various items of information arriving at the SON and the response to osmotic variation.

The aim of this study was to determine the role of Dp71 in the response of the SON and the NH following 8 days of salt loading in Dp71-null mice. We analyzed plasma osmolality and AVP synthesis and release, and we localized and quantified dystrophins in the SON and neurohypophysis.

\section{MATERIALS AND METHODS}

\section{Animals and Maintenance Conditions}

All experiments were performed in accordance with French and European legal requirements (decree 87-848). Experiments were performed on 6-week-old male Balb/c mice (supplied by Janvier, France) and Dp71-null mice bred from mice provided by Drs. D. Yaffe and U. Nudel at the Weizmann Institute of Science, Rehovot, Israel. In Dp71-null mice, Dp71 was specifically inactivated by replacing its first, unique exon and part of its intron with the $\beta$-galactosidase reporter gene (Sarig et al., 1999).

All animals were housed under controlled conditions and provided with food and water ad libitum. Control animals were given free access to water, and dehydrated animals were supplied with drinking water containing $2 \% \mathrm{NaCl}$, ad libitum, for 8 days. We set up groups of three animals for immunohistochemistry and in situ hybridization, five to six animals for enzyme immunoassay, and six to ten animals for Western blotting. All experiments were repeated three to five times.

\section{Evaluation of Liquid Intake and Plasma Osmolality}

We determined the liquid intake of each mouse daily on each of the 8 days of the experiment and expressed it in milliliters per day. At the end of the 8 days, each mouse was anesthetized with $4 \%$ isoflurane and decapitated, and its blood was collected in a heparin-containing tube packed in ice. Plasma was obtained by centrifugation at $2,500 \mathrm{~g}$ for $20 \mathrm{~min}$ at $4^{\circ} \mathrm{C}$ and osmolality determined for $100 \mu \mathrm{l}$ of plasma, using an osmometer (BioBlock Scientific, France)

\section{Enzyme Immunoassay}

Brains were removed immediately after decapitation, and thick $(400 \mu \mathrm{m})$ frontal sections of the hypothalamus area were cut with a vibroslice. Both SON were punched out, and the neurohypophysis $(\mathrm{NH})$ was rapidly removed and stored at $-20^{\circ} \mathrm{C}$. For peptide extraction, SON and $\mathrm{NH}$ samples were immersed separately in $100 \mu \mathrm{l}$ of $0.01 \mathrm{M}$ phosphate buffer

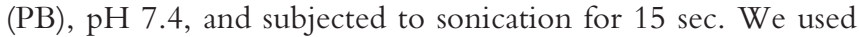
$10 \mu \mathrm{l}$ of the resulting homogenate for protein assays with the Coomassie Plus Bradford Assay Kit (Perbio Science, France). The remaining $90 \mu \mathrm{l}$ of the sample was mixed with $90 \mu \mathrm{l}$ of $4 \mathrm{M}$ acetate, heated $\left(10 \mathrm{~min} ; 95^{\circ} \mathrm{C}\right)$ and centrifuged $(50 \mathrm{~min}$; $\left.13,000 \mathrm{rpm} ; 4^{\circ} \mathrm{C}\right)$. The resulting supernatants were decanted into a fresh tube and dried in a speed vacuum. The resulting residues were dissolved in EIA buffer containing 0.1 $\mathrm{M} \mathrm{PB}$, $\mathrm{pH} 7.4,0.15 \mathrm{M} \mathrm{NaCl}, 0.1 \%$ bovine serum albumin (BSA), and $0.01 \%$ sodium azide.

The AVP content of the extracted samples was determined by competitive enzyme immunoessay (EIA; Vacher et al. 2002). Solid-phase EIA was performed in anti-rabbit antibody-coated microtitration plates (Immunoplate Maxisorp; Nunc, Glostrup, Denmark), to which various reactants were added: peptide standard or sample, enzymatic tracer, and diluted rabbit antibody against AVP (1:50,000; Alonso, 1988). After $18 \mathrm{hr}$ of incubation at $4^{\circ} \mathrm{C}$, the enzymatic activity of the immune complex bound to the solid phase was evaluated by adding Ellman's medium and measuring the absorbance of each well at $414 \mathrm{~nm}$. The sensitivity of the assay was determined as described by Vacher et al. (2002). The AVP concentration of the samples was calculated from the standard curves and standardized with respect to the total amount of protein.

\section{In Situ Hybridization}

Mice were deeply anesthetized with pentobarbital $(25 \mathrm{mg} / \mathrm{kg})$ and transcardially perfused with saline $(0.9 \%$ $\mathrm{NaCl}$ ), followed by $2 \%$ paraformaldehyde (PFA). Brains were removed and postfixed ( $2 \mathrm{hr}$ ), cryoprotected, and sectioned (20 $\mu \mathrm{m}$; Leica CM 300). Lipids were removed, and sections of the SON were hybridized for $18 \mathrm{hr}$ at $42^{\circ} \mathrm{C}$ with an AVP oligonucleotide probe (Trembleau et al., 1993) labeled at the $3^{\prime}$ end with digoxygenin (DIG Oligonucleotide Tailing Kit, second generation; Roche, France) and diluted in hybridization buffer $(50 \%$ formamide, $600 \mathrm{mM} \mathrm{NaCl}, 80 \mathrm{mM}$ Tris$\mathrm{HCl}, \mathrm{pH} 7.5,4 \mathrm{mM}$ EDTA, 0.05\% disodium pyrophosphate, $0.05 \%$ tetrasodium pyrophosphate, $0.2 \% \quad N$-lauryl sarcosyl, 
$500 \mu \mathrm{g} / \mathrm{ml}$ salmon testis DNA, 1\% dextran sulfate, and $1 \%$ Denhardt's solution). The slides were then washed $\left(42^{\circ} \mathrm{C}, 2 \times\right.$ SSC; $1 \times$ SSC; $0.5 \times$ SSC; room temperature, $0.1 \times$ SSC) and processed for the immunodetection of digoxigenin (Esclapez et al., 1996) with an anti-DIG antibody conjugated to alkaline phosphatase (Roche, France). The NBT/BCIP precipitate was observed under a light microscope.

\section{Immunohistochemistry}

Tissues were prepared using the same procedure as for in situ hybridization, except that the fixative solution contained 4\% paraformaldehyde. For double immunohistochemistry, sections of SON and NH were permeabilized and blocked by incubation for $1 \mathrm{hr}$ with $0.05 \mathrm{M}$ PBS, pH 7.4, 1\% BSA, and $0.2 \%$ Triton $\mathrm{X}-100$, then incubated overnight with both a polyclonal rabbit antibody against dystrophins, H4 (1:400; Royuela et al., 2003), and the mouse anti-AVP antibody $(1: 5,000$; Robert et al., 1985), the mouse anti-GFAP antibody (1:200; Sigma, France), or the rat anti-CD31/PECAM-1 antibody (1:400; BD Biosciences Pharmingen, France) diluted in PBS, $1 \%$ BSA, $0.2 \%$ Triton. The sections were then incubated for $2 \mathrm{hr}$ with biotinylated anti-rabbit IgG antibodies (1:250; Vector Laboratories, Burlingame, CA) and then for $2 \mathrm{hr}$ with both streptavidin Cy3 conjugate (1:250; Vector Laboratories) and FITC-conjugated anti-mouse secondary antibodies (1:250; Vector Laboratories) or anti-rat IgG conjugated to Alexa Fluor 488 (1:400; Invitrogen, France). Fluorescence was observed with a Zeiss Axioskop 2 Plus fluorescence microscope, and images were captured with a Zeiss AxioCam HRc digital camera and Axiovision version 4.1 software.

\section{Electrophoresis and Blotting}

The SON and neurohypophysis were collected by using the same procedure as for EIA. The punched out tissue samples for each group, pooled in twos, were homogenized in lysis buffer $(50 \mathrm{mM}$ Tris- $\mathrm{HCl}, \mathrm{pH} 7.2,150 \mathrm{mM} \mathrm{NaCl}, 0.1 \%$ sodium dodecyl sulfate, $0.01 \%$ sodium deoxycholate) supplemented with $1 \%$ protease inhibitor cocktail (Sigma, France). The homogenate was centrifuged $\left(10 \mathrm{~min} ; 13,000 \mathrm{rpm} ; 4^{\circ} \mathrm{C}\right)$, and total protein concentration in the supernatant was estimated with the Coomassie Plus Bradford Assay Kit (Perbio Science, France). Each sample was denatured in $2 \times$ Laemmli sample buffer (Sigma, France) by heating for $5 \mathrm{mn}$ at $95^{\circ} \mathrm{C}$. Total protein $(20 \mu \mathrm{g})$ was subjected to electrophoresis $(150 \mathrm{~V})$ on NuPAGE 4-12\% Bis-Tris gels (Invitrogen, France) in MOPS-SDS running buffer, and the bands obtained were electrotransferred (2 hr; $\left.400 \mathrm{~mA} ; 4^{\circ} \mathrm{C}\right)$ onto PVDF membranes (Sigma, France). Blots were blocked by incubation for $1 \mathrm{hr}$ at room temperature with 5\% nonfat milk powder (Bio-Rad, Hercules, CA) in PBS and 0.1\% Tween 20 and were then incubated overnight at $4^{\circ} \mathrm{C}$ with the primary antibodies H4 $(1: 5,000)$ or anti- $\beta$-actin antibody $(1: 7,500$; Chemicon, France) diluted in the same solution. Antibody binding to blots was detected by incubation with horseradish peroxidase (HRP)-labeled goat anti-rabbit or anti-mouse secondary antibodies (1:5,000; Interchim, France) and the ECL Plus detection system (GE Healthcare, United Kingdom), using Kodak Biomax Light $1 \mathrm{film}$. Protein levels on blots were estimated arbitrarily with TotalLab TL120 (Nonlinear Inc., Durham, NC).

\section{Statistical Analysis}

All numerical results are expressed as means \pm SEM and were compared in a one-way ANOVA, followed by Scheffe's test. Differences were considered statistically significant at $P<0.05$.

\section{RESULTS}

\section{Differences in Liquid Intake and Plasma Osmolality Between Dp71-Null Mice and the Wild Type}

Animals were assigned to four groups: wild-type/ control, wild-type/salt loading, Dp71-null/control, and Dp71-null/salt loading. We investigated the possible effects of a lack of Dp71 on osmoregulation by comparing the daily liquid intake (Fig. 1A) and plasma osmolality (Fig. 1B) of Dp71-null mice with those of wild-type mice, under control and salt-loading conditions.

Under control conditions, liquid intake was similar in wild-type $(3.61 \pm 0.07 \mathrm{ml})$ and Dp71-null mice $(3.79 \pm 0.18 \mathrm{ml})$. Salt loading led to an increase in liquid intake in both groups, but this increase was significantly greater in Dp71-null mice $(8.35 \pm 0.148 \mathrm{ml})$ than in their wild-type counterparts $(5.37 \pm 0.09 \mathrm{ml}$; $P<0.05)$. Under control conditions, Dp71-null mice had a lower $(P<0.05)$ plasma osmolality than wild-type mice $\left(287.58 \pm 7.45 \mathrm{mosmol} / \mathrm{kg} \cdot \mathrm{H}_{2} \mathrm{O}\right.$ vs. $306.44 \pm$ $\left.2.16 \mathrm{mosmol} / \mathrm{kg} \cdot \mathrm{H}_{2} \mathrm{O}\right)$. Under salt-loading conditions, this difference between Dp71-null mice and wild-type mice was maintained $\left(279.16 \pm 10.42 \mathrm{mosmol} / \mathrm{kg} \cdot \mathrm{H}_{2} \mathrm{O}\right.$ vs. $\left.305.94 \pm 2.34 \mathrm{mosmol} / \mathrm{kg} . \mathrm{H}_{2} \mathrm{O}\right)$. However, in both wild-type and Dp71-null mice, a comparison of plasma osmolality values showed no significant difference between control and salt-loaded mice, suggesting that Dp71-null mice are as able to cope with salt loading as wild-type mice.

\section{AVP Levels in Dp71-Null and Wild-Type Mice}

AVP levels were evaluated after 8 days of salt loading in Dp71-null mice and compared with those in the wild type. The AVP peptide was quantified by EIA in the SON and NH, and AVP mRNA in the SON was visualized by in situ hybridization.

Under control conditions, comparisons of AVP peptide levels in the SON (Fig. 1C) and NH (Fig. 1D) between Dp71-null and wild-type mice showed that Dp71-null mice had more AVP in the SON than wildtype mice, whereas no difference between the strains was observed for the NH. Eight days of salt loading led to a significant and large increase $(P<0.05)$ in AVP levels in the SON and NH of wild-type mice. By contrast, salt loading significantly decreased AVP levels $(P<$ 0.05 ) in the SON (with a nonsignificant decrease in the $\mathrm{NH}$ ) in Dp71-null mice. 


\section{$\square_{\text {wt/Ctrl }} \square_{\text {Dp71-null/Ctrl }}$ \\ $\square_{\text {wt/SL }} \square_{\text {Dp71-null/SL }}$}

A
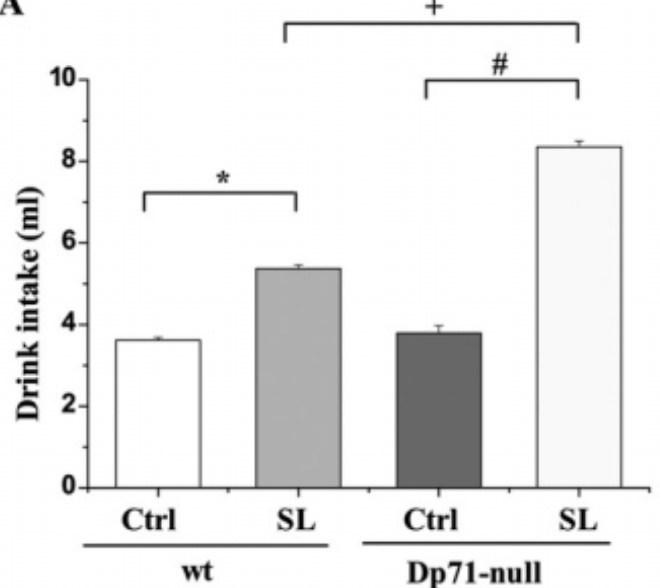

c
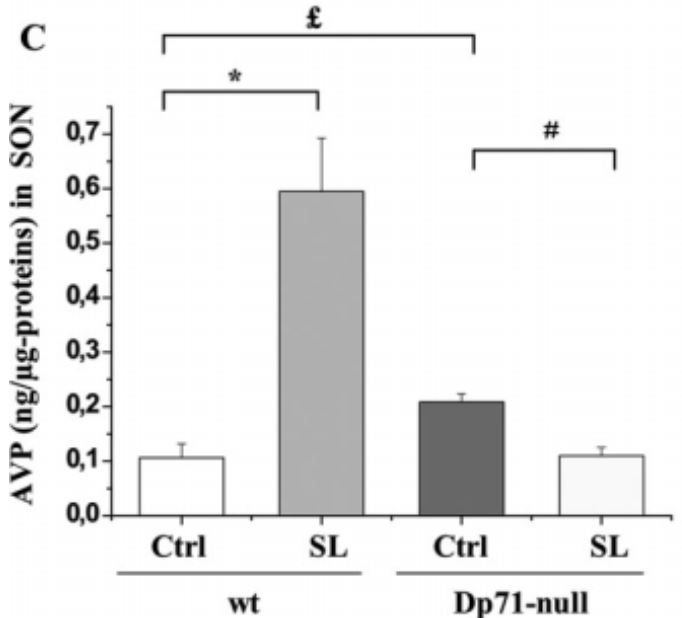
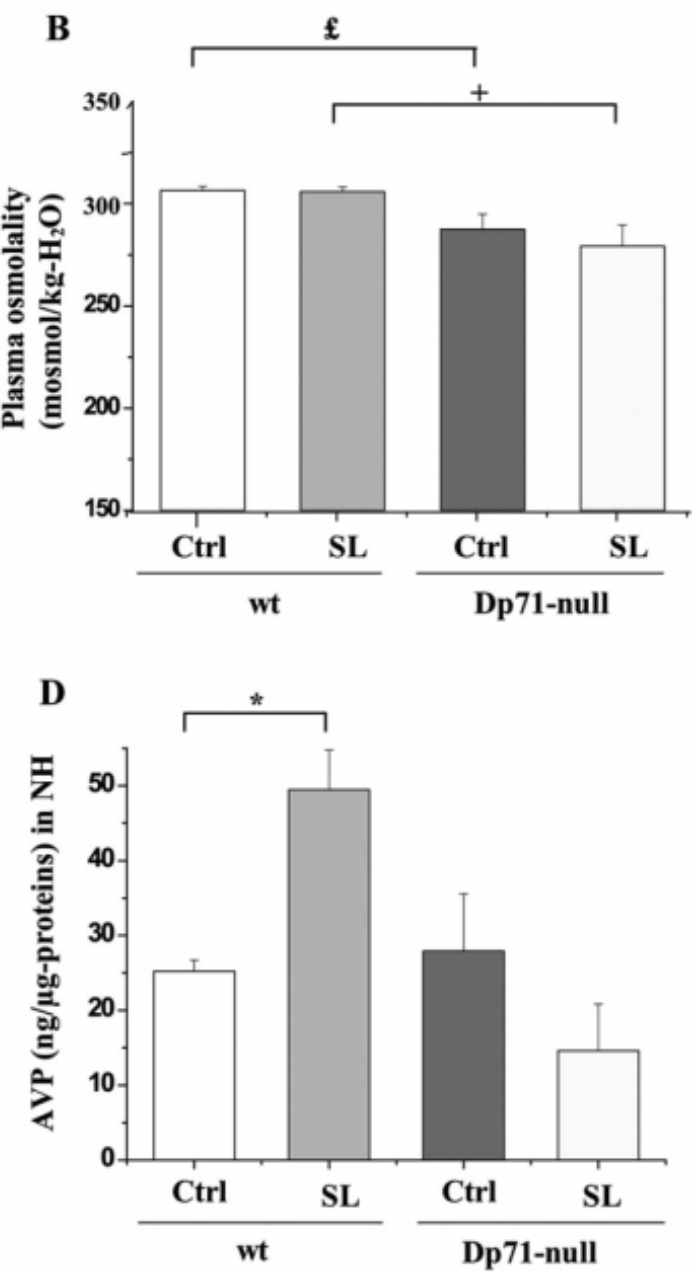

Fig. 1. A: Daily intake of water (Ctrl) and 2\% saline solution (SL) in Dp71-null mice and their wild-type counterparts (wt). B: Plasma osmolality of Dp71-null and wild-type mice under Ctrl and SL conditions. C,D: AVP content, determined by enzyme immunoassay, in the supraoptic nucleus (C) and the neurohypophysis (D) of Dp71-null and wild-type mice under Ctrl and SL conditions. Values are expressed as means \pm SEM ( $\mathrm{n}=5-6$ mice for each time point). $*, \#,+, \AA_{P}<0.05$.

In situ hybridization analysis showed the AVP mRNA signal to be similar in Dp71-null mice (Fig. 2B) and wild-type mice (Fig. 2A). Salt-loading increased the intensity of the signal in both groups, but this increase was much greater in the wild-type (Fig. 2C) than in the Dp71-null (Fig. 2D) mice. Thus, EIA and ISH data indicate that Dp71-null mice retain the ability to synthesize higher amounts of AVP under conditions of salt loading but that the response of the hypothalamoneurohypophysis system is attenuated in these mice.
DMD Gene Products in the SON and NH of Dp71-Null Mice Before and After Salt Loading

We investigated the products of the DMD gene in the hypothalamoneurohypophysis system of wild-type and Dp71-null mice, analyzing their levels in normal conditions and after 8 days of salt loading. We analyzed SON and NH extracts from all groups by immunoblotting with $\mathrm{H} 4$, an antibody directed against dystrophins (Royuela et al., 2003). Two major dystrophin bands, corresponding to Dp140 and Dp71, were detected in 

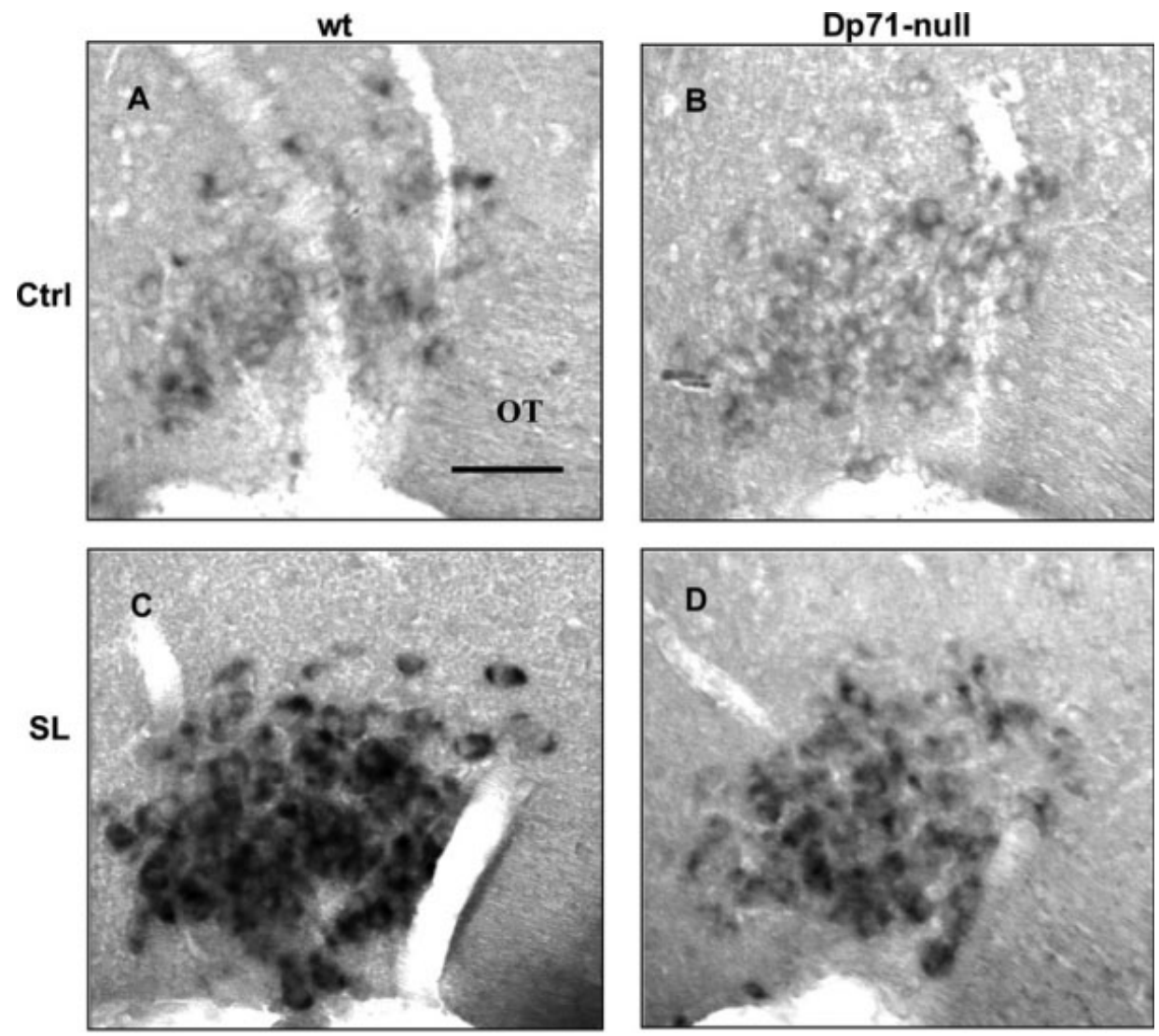

Fig. 2. AVP mRNA detection by in situ hybridization in the SON of Dp71-null mice $(\mathbf{B}, \mathbf{D})$ and wild-type mice $(\mathbf{A}, \mathbf{C})$ under control conditions $(\mathrm{A}, \mathrm{B})$ and after salt loading $(\mathrm{C}, \mathrm{D})$. In both wild-type and Dp71-null mice, AVP mRNA labeling was detected within the

wild-type mice, but only the Dp140 band was observed in Dp71-null mice, as expected (Fig. 3A).

Interestingly, in the SON, an additional band below the Dp140 band was detected in both wild-type and Dp71-null mice. Moreover, traces of Dp260 were detected in the NH of Dp71-null mice (Fig. 3A). No significant changes in Dp71 or Dp140 levels were observed in either the SON or the NH after salt loading (Fig. 3B,C).

\section{Distribution of Dystrophins in the SON of Dp71-Null and Wild-Type Mice Before and After Salt Loading}

For the identification of dystrophin-producing cells in control and salt-loaded mice and investigation of the effects of an absence of Dp71 on the distribution of these proteins, we double immunostained the SON with $\mathrm{H} 4$, which recognizes all DMD gene products, together with an antibody against AVP, GFAP or CD31, or DAPI.

In wild-type mice, dystrophin labeling was observed above the ventral glial limitans (VGL) and around blood vessels (Fig. 4A), appearing in the fine capillaries after salt loading (Fig. 4B). In Dp71-null mice,
SON and was more intense after salt loading in Dp71-null (C and D, respectively) than under $\mathrm{Ctrl}$ conditions ( $\mathrm{A}$ and $\mathrm{B}$, respectively). The intensity of staining after SL was higher in wild-type than in SL Dp71-null mice. Scale bar $=60 \mu \mathrm{m}$.

no dystrophin signal was detected around vessels, whereas such a signal was detected in the SON neurons, where its intensity increased slightly after salt loading (Fig. 4C,D). In the absence of Dp71, dystrophin immunolabeling was restricted to the perinuclear area (Fig. 4Q and inset) of AVP-positive magnocellular neurons (Fig. 4N and inset). By contrast, no colocalization of dystrophins and AVP was observed in the magnocellular neurons of the wild-type SON (Fig. 4M and inset).

The changes in AVP level detected were also observed on immunohistochemistry: similar levels in wild-type mice (Fig. 4E) and Dp71-null mice (Fig. 4G) under control conditions, with a slight increase after salt loading in Dp71-null mice (Fig. 4H) and a large increase after salt loading in wild-type mice (Fig. 4F). In the vessels of wild-type mice, the colocalization of dystrophins and CD31 (Fig. 4R and inset) or GFAP (Fig. 4O and inset) confirmed the presence of dystrophins within endothelial cells and in the perivascular astrocyte endfeet, as reported for other areas of the brain (Jancsik and Hajos, 1999). GFAP immunolabeling was more intense in the VGL of Dp71-null mice (Fig. 4K,L) than in that of wild-type mice (Fig. 4I,J), and dual-immunofluores- 
cence staining for dystrophins and GFAP demonstrated more intense double staining in Dp71-null mice (Fig. 4P and inset) than in the wild type (Fig. 4O).
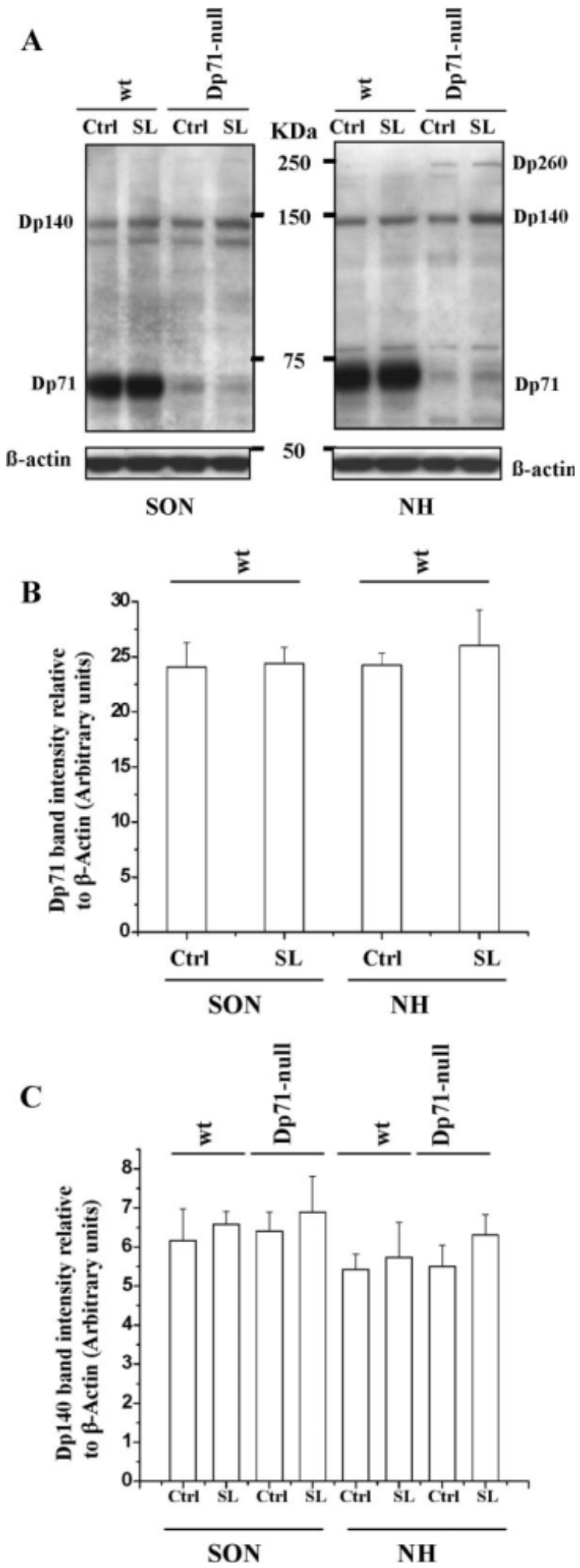

Distribution of Dystrophins in the NH of Dp71-Null and Wild-Type Mice Before and After Salt Loading

We investigated the distribution of dystrophins in the $\mathrm{NH}$ of control and salt-loaded mice and investigated whether the absence of Dp71 affected the distribution of these proteins or AVP neurons and glial cells, by immunolabeling the $\mathrm{NH}$ with $\mathrm{H} 4$, anti-AVP, and anti-GFAP antibodies. In wild-type mice, the dystrophin signal was detected around blood vessels (Fig. $5 \mathrm{~A})$, and its intensity was not affected by salt loading (Fig. 5B). In Dp71-null mice, dystrophin immunolabeling, which was less important than that of wild-type (Fig. 5C), was also unaffected by salt loading (Fig. 5D). In addition, the variations of AVP level observed on EIA were also observed on immunohistochemistry, with a similar signal intensity in wild-type mice (Fig. 5E) and Dp71-null mice (Fig. 5G) in control mice, a slight decrease after salt-loading in Dp71-null mice (Fig. $5 \mathrm{H}$ ), and a larger increase after salt loading in wild-type mice (Fig. 5F).

In Dp71-null mice, GFAP immunofluorescence in the glial cells, both under control conditions and after salt loading, demonstrated a marked change in the morphology of pituicyte end-feet, which appeared looser (Fig. 5K,L) than the more compact end-feet of the wild type (Fig. 5I,J). Thus, an absence of Dp71 affects both the synthesis and the release of AVP and the morphology and the physiology of pituicytes.

\section{DISCUSSION}

Dp71 and, to a lesser extent, Dp140 are the major dystrophin proteins present in both the SON and the NH. We investigated the importance of these molecules for the function of these structures, by comparing the physiological parameters of Dp71-null mice with those of wild-type mice under control and saltloading conditions. The collected data indicate that dystrophins, and Dp71 in particular, play a key role not only in osmoregulation but also in defining the "osmostat."

Fig. 3. Western blotting revealed the presence of Dp71 and Dp140 in the SON and NH of wild-type mice (A). As expected, the 71$\mathrm{kDa}$ band was not detected for Dp71-null mice (A). SL did not affect the intensity of the Dp140 (in Dp71-null and wild-type mice) and Dp71 (in the wild type) bands in the SON and NH. Note the presence of a third band below Dp140 in the SON of all animals and the trace of Dp260 in the NH of Dp71-null mice. Molecular weight markers are indicated between the two gels. The DMD products detected are indicated at left for SON and at right for NH. The relative levels of Dp71 and Dp140 (B and C, respectively) are shown in arbitrary units as the mean \pm SEM ( $\mathrm{n}=5-6$ for each point). Each value represents the ratio of the staining intensity for the specific band normalized with respect to $\beta$-actin, used as a loading control (TotalLab TL120; Nonlinear Inc., Durham, NC). 

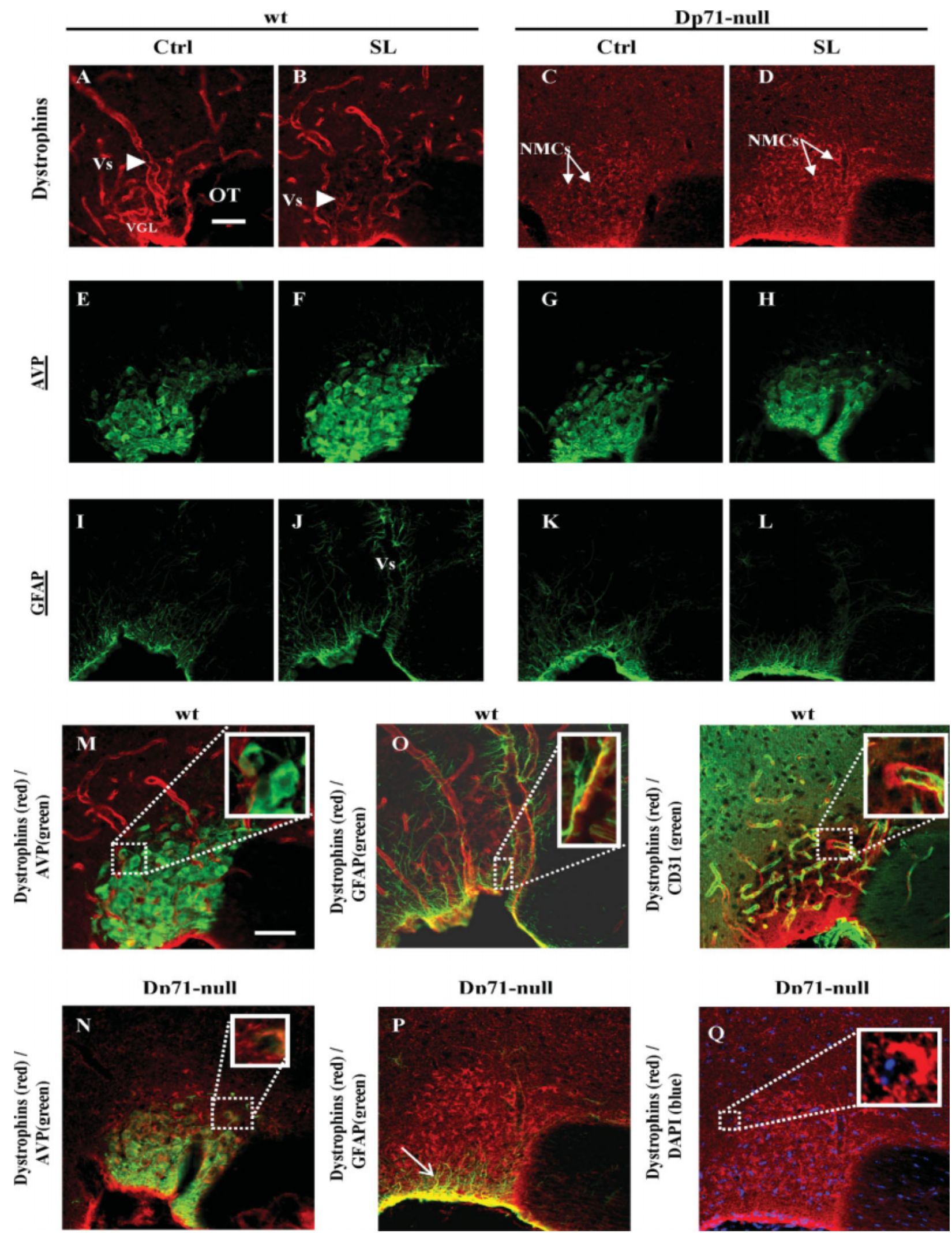

Fig. 4. A-Q: Immunohistochemical detection of dystrophins in the SON of wild-type mice, before and after salt loading, above the VGL, in the blood vessels (A,B, white arrowheads), where it was colocalized with GFAP (O and inset) and with CD31 ( $Q$ and inset). By contrast, in the SON of Dp71-null mice, no dystrophins are found in the vessels, but these molecules are detected in the magnocellular neurons (C,D, arrows), surrounding DAPI-labeled nuclei (Q and inset) and colocalizing with AVP immunolabeling ( $\mathrm{N}$ and inset). In addition, in the absence of Dp71, the dystrophins present in the VGL colocalized with GFAP (P and arrow). OT, optic tract; Vs, vessels; VGL, ventral glial limitans; AVP, arginine vasopressin; GFAP, glial fibrillary acidic protein; DAPI, 4,6-diamidino-2-phenylindole dihydrochloride. Scale bars $=60 \mu \mathrm{m}$ in A (applies to A-L);60 $\mu \mathrm{m}$ in $\mathrm{M}$ (applies to $\mathrm{M}-\mathrm{Q}$ ). 

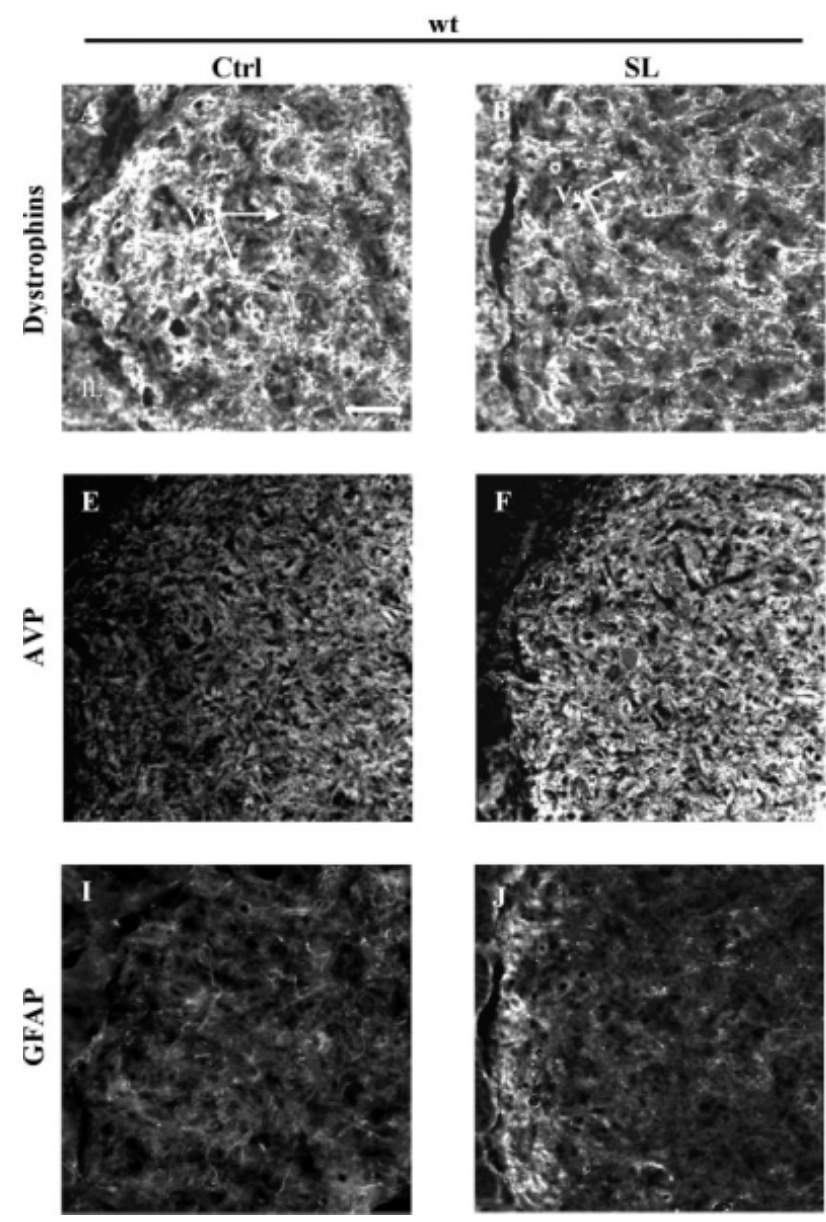

Fig. 5. Immunohistochemical detection of dystrophins around vessels in the neurohypophysis of wild-type $(\mathbf{A}, \mathbf{B})$ and Dp71-null mice $(\mathbf{C}, \mathbf{D})$. The intensity of dystrophin immunostaining was lower in Dp71-null mice than in wild-type mice. In both Dp71-null and wild-type mice, salt loading had no effect on the intensity of the dystrophin signal (B,D, respectively). AVP immunolabeling in wild-type

\section{Expression and Distribution of Dystrophins in the} SON of Wild-Type and Dp71-Null Mice

In control wild-type mice, dystrophins are produced in the SON, principally in the form of Dp71 and Dp140, as shown by Western blotting. Immunohistochemistry for dystrophins and cellular markers revealed that dystrophins are not produced by MCNs but are instead found in endothelial cells and astrocyte cell bodies and end-feet, as reported by Loufrani et al. (2001) and Schofield et al. (1994).

A fine analysis of the superposition of dystrophins and GFAP showed dystrophin labeling surrounding the vessels but not in the whole extension of astrocyte processes. This confirms that dystrophins, synthesized in astrocyte cell bodies, are targeted to their active sites in the membrane, as suggested by Jancsik and Hajos (1999). In the SON, endothelial cells and astrocyte end-feet are
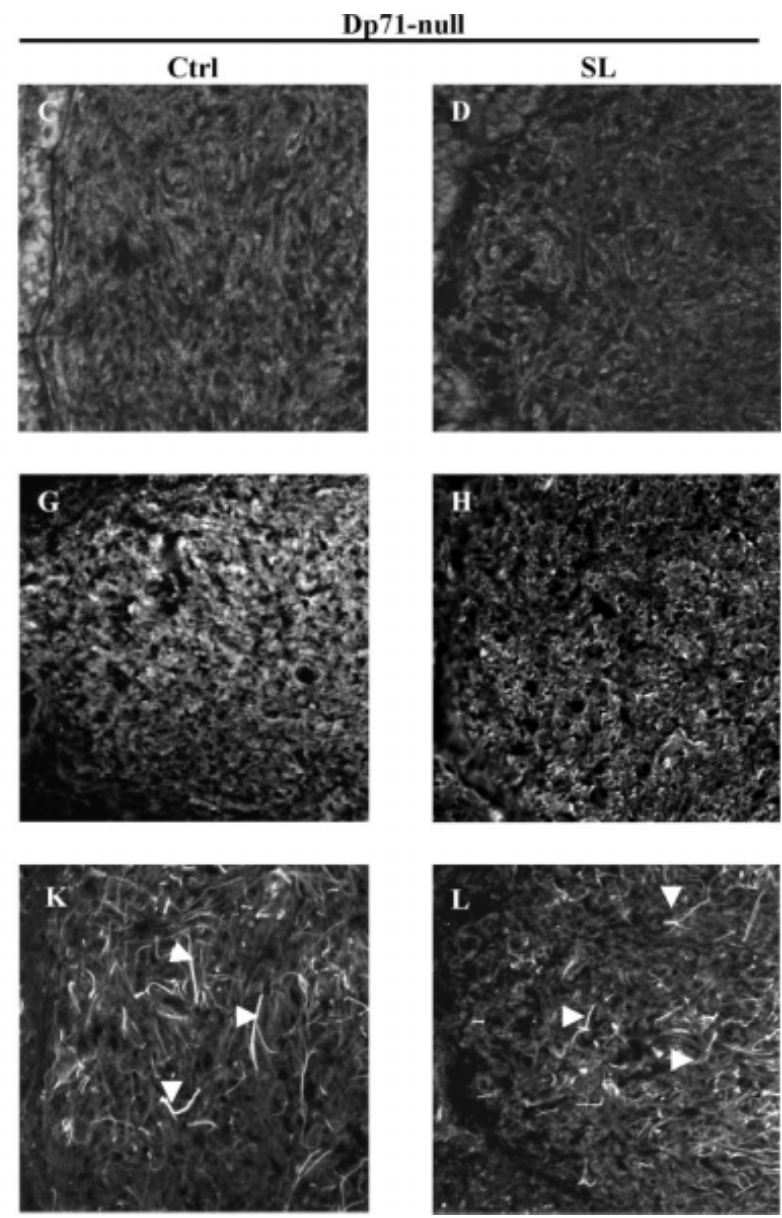

(E) and Dp71-null (G) mice was similar under control and salt-loading conditions, but salt loading increased AVP signal intensity strongly in the $\mathrm{NH}$ of wild-type mice $(\mathbf{F})$, whereas it decreased the intensity of this signal in Dp71-null $(\mathbf{H})$ mice. Note the change in morphology of the pituicyte end-feet in Dp71-null $(\mathbf{K}, \mathbf{L})$ mice, as shown by comparison with the wild type $(\mathbf{I}, \mathbf{J})$. Scale bar $=60 \mu \mathrm{m}$. physiologically associated with osmoreception. Indeed, information about plasma osmolality is conveyed to MCNs via the osmosensitive loop involving circumventricular organs and directly through a pathway consisting of capillary endothelial cells and SON astrocyte end-feet. The presence of dystrophins in brain microvessels and in the end-feet of perivascular astrocytes has been associated with blood-brain barrier functions (Nico et al., 2003). Our data therefore strongly suggest that dystrophins in the perivascular area of the SON may be involved in the intrinsic osmosensitivity of this structure.

The absence of dystrophin immunolabeling in the perivascular area and its persistence in the VGL in the absence of Dp71 suggest that Dp71 is the major DMD gene product in endothelial cells and astrocyte end-feet. Indeed, Dp71 has been detected in astrocyte cultures (Imamura and Ozawa, 1998) and in the glial cell end- 
feet of the choroid plexus and brain microvasculature (Haenggi et al., 2004). This also suggests that Dp 140 may be synthesized in and confined to the astrocytes cell bodies in the VGL.

However, one of the most striking findings of our study was the expression of dystrophins in AVP MCNs in the Dp71-null but not in the wild-type SON. The isoform produced was certainly Dp140, as demonstrated by immunoblots. This localization of Dp140 just below the membrane, in the soma of AVP neurons in Dp71null mice, suggests that this protein may be involved in integrating external informations from presynaptic inputs in the SON of these mice. A similar modification to the cellular pattern of dystrophin production and distribution has already been observed in other structures, in the absence of one member of the dystrophin family. This change has physiological consequences in these models, because dystrophins are responsible for the clustering and anchorage to the membrane of various ion channels and signaling proteins (Hernandez-Gonzalez et al., 2005; Fort et al., 2008). Up-regulation of utrophin, a wellknown dystrophin-related protein associated with the DAPC (Blake et al., 2002), has also been reported following the disruption of dystrophin gene expression (Dalloz et al., 2003; Fort et al., 2008). However, in HNHS structures, the absence of Dp71 does not seem to lead to an increase in utrophin levels (data not shown).

\section{Expression and Distribution of Dystrophins in the NH of Wild-Type and Dp71-Null Mice}

In the $\mathrm{NH}$, wild-type mice displayed immunolabeling for Dp71 and Dp140 around vessels. Such a distribution associated with postsynaptic membranes has already been demonstrated in other regions of the brain with high levels of plasticity (Lidov et al., 1990; Kim et al., 1992).

However, the neurohypophyseal response to the disruption of Dp71 differs from that in the SON, insofar as it resulted in the apparition of Dp260. An unusual change in the appearance of $\mathrm{GFAP}^{-}$processes was also observed, with looser, more widely spread pituicyte end-feet. In a recent study, Fort et al. (2008) described a similar morphological change in Dp71-null Muller cells, probably related to the role of Dp71 to anchor the DAPC to the cell membrane and the interaction with the extracellular matrix (Dalloz et al., 2003).

\section{Effects of Salt Loading on Dystrophin Expression and Distribution in the SON and NH of Wild-Type and Dp71-Null Mice}

To determine whether the morphological modifications observed in Dp71 mice have functional consequences for the HNHS physiology, we subjected the two mouse strains to salt loading. This paradigm is known to induce an osmoregulatory response without stimulating the HPA stress axis. In the first days of salt loading, AVP release is increased. This is accompanied by a progressive elevation of AVP synthesis, but the plasmatic osmolality remains high. After 8 days of salt loading, the osmoregulatory response reaches a steady-state level, with increased AVP synthesis and release, and a normal osmolality level is restored (Dai and Yao, 1995; Arima et al., 1999; Kondo et al., 2004). With these conditions, we analyzed changes in dystrophin production in the two strains after 8 days of salt loading and then compared the capacity of the HNHS in the two strains to deal with osmotic stimulation.

In the SON of wild-type and Dp71-null mice, salt loading had no effect on the global production of Dp71 and/or Dp140, dystrophin labeling being detected mostly in the fine capillaries of wild-type mice after salt loading. In the NH also, salt loading did not affect dystrophin levels in wild-type or Dp71-null mice. However, the distribution of Dp71 and/or Dp140 in the membranes of the $\mathrm{NH}$ is modified, as for the SON. Under conditions of chronic dehydration, the pituicyte end-feet connecting the axonal terminals and capillary vessels retract, resulting in the axonal terminals contacting the basal lamina (Tweedle and Hatton, 1987). This process seemed not to occur in Dp71-null mice and could suggest that the presence of Dp71 confers upon pituicytes the ability to retract and reinsert, through changes in the anchorage, organization of DAPC components, and their interaction with the actin cytoskeleton. Indeed, plasticity of the pituicytes is known to involve transition between nonstellate and stellate states, accompanied by changes in actin polymerization and reorganization of the microtubular system (Theodosis, 2002; Rosso and Mienville, 2009). This point is worthy of further investigation, namely, by analysis of expression and distribution of MAP2, which is known to be a suitable marker with which to evaluate pituicyte functionality (Matsunaga et al., 1999).

\section{Functional Analysis: Changes in Plasma Osmolality and AVP Transcription, Synthesis, and Release in Dp71-Null Mice}

After 8 days of salt loading, wild-type mice have a plasma osmolality that has returned to the control level. This is accompanied by an increase in drink intake and an elevation in AVP synthesis, as usually described (Dai and Yao, 1995; Arima et al., 1999; Kondo et. al., 2004). In the Dp71-null mice also, 8 days of salt loading increased AVP mRNA, as demonstrated by ISH, although this increase was smaller than that observed in wild-type mice. It is associated with an increase in AVP export, insofar as the AVP neuropeptide content was reduced in the SON of SL-Dp71-null mice, and the same pattern is observed in the NH. This neurohormonal response was associated with the maintenance of plasma osmolality and an increase in liquid intake after salt loading. Altogether, these findings demonstrate that Dp71-null mice retain a functional HNHS.

However, the capacity of the HNHS to react to salt loading is different between Dp71-null and wild-type 
mice, in that AVP levels decreased in the mutants but not in the wild-type mice (in which AVP content actually increased in both the SON and the NH). The HNHS of Dp71-null mice therefore seems to "tire out" under salt-loading conditions. This could be due to the lack of Dp71 and to the neuronal expression of Dp140, which may modify signal integration in the SON and disturb the fine-tuning of expression and the release of AVP. The structural modifications observed in the neurophypophysis of the Dp71-null mice may also be involved in this process, insofar as the AVP content of the $\mathrm{NH}$ affects the release of this neuropeptide (Miller and Moses, 1971).

Nevertheless, the most striking observation concerning the osmotic parameters was the lower basal plasma osmolality in the Dp71-null than in wild-type mice. This lower osmolality was maintained under saltloading conditions, confirming the functional integrity of the HNHS, and did not result from differences in liquid intake, suggesting that this modification may be of central origin. The hypoosmolar status of Dp71-null mice could potentially be the result of the establishment of a new set point for osmoregulation in the hypothalamus: the "osmostat," by analogy to "thermostat" and "lipostat." Such a resetting of the osmotat could be the consequence of the observed modifications in the osmoreceptive pole of the SON constituted by endothelial cells, astrocyte end-feet, and magnocellular soma. By contrast, in the $\mathrm{NH}$, the effector pole, the presence of Dp71 in perivascular pituicyte end-feet may play a role in the relationships between neuronal terminals and pituicytes responsible for adjusting the release of AVP in response to physiological state.

Finally, and to return to the pathology, recent studies described symptomatic nephrolithiasis in patients with Duchenne muscular dystrophy (Singh et al., 2007; Shumyatcher et al., 2008). One of the origins of stone disease is a reduction in urinary volume, and this has been observed in DMD patients (Shumyatcher et al., 2008). Such a decrease in urinary volume could be the consequence of a hypoosmolar status resulting from the disruption of dystrophin expression in the brain.

\section{REFERENCES}

Alonso G. 1988. Effects of colchicine on the intraneuronal transport of secretory material prior to the axon: a morphofunctional study in hypothalamic neurosecretory neurons of the rat. Brain Res 453:191-203.

Arima H, Kondo K, Kakiya S, Nagasaki H, Yokoi H, Yambe Y, Murase T, Iwasaki Y, Oiso Y. 1999. Rapid and sensitive vasopressin heteronuclear RNA responses to changes in plasma osmolality. J Neuroendocrinol 11:337-341.

Austin RC, Morris GE, Howard PL, Klamut HJ, Ray PN. 2000. Expression and synthesis of alternatively spliced variants of Dp71 in adult human brain. Neuromusc Disord 10:187-193.

Blake DJ, Weir A, Newey SE, Davies KE. 2002. Function and genetics of dystrophin and dystrophin-related proteins in muscle. Physiol Rev 82:291-329.

Bourque CW. 1998. Osmoregulation of vasopressin neurons: a synergy of intrinsic and synaptic processes. Prog Brain Res 119:59-76.
Brazeau GA, Mathew M, Entrikin RK. 1992. Serum and organ indices of the mdx dystrophic mouse. Res Commun Chem Pathol Pharmacol 77:179-189.

Dai WJ, Yao T. 1995. Effects of dehydration and salt-loading on hypothalamic vasopressin mRNA level in male and female rats. Brain Res 676:178-182.

Dalloz C, Sarig R, Fort P, Yaffe D, Bordais A, Pannicke T, Grosche J, Mornet D, Reichenbach A, Sahel J, Nudel U, Rendon A. 2003. Target inactivation of dystrophin gene product Dp71: phenotypic impact in mouse retina. Hum Mol Genet 13:1543-1554.

Esclapez M, Chang DK, Houser CR. 1996. Subpopulations of GABA neurons in the dentate gyrus express high levels of the alpha 1 subunit of the $\mathrm{GABA}_{\mathrm{A}}$ receptor. Hippocampus 6:225-238.

Fort P, Sene A, Pannicke T, Roux MJ, Forster V, Mornet D, Nudel U, Yaffe D, Reichenbach A, Sahel JA, Rendon A. 2008. Kir4.1 and AQP4aAssociate with Dp71- and utrophin-DAPs complexes in specific and defined microdomains of Muller retinal glial cell membrane. Glia 56:597-610.

Ghorbel MT, Sharman G, Hindmarch C, Becker KG, Barrett T, Murphy D. 2006. Microarray screening of supression subtractive hybridizationPCR cDNA libraries identifies novel RNAs regulated by dehydration in the rat supraoptic nucleus. Physiol Genom 24:163-172.

Gorecki DC, Barnard EA. 1995. Specific expression of G-dystrophin (Dp71) in the brain. Neuroreport 6:893-896.

Griffin JL, Williams HJ, Sang E, Clarke K, Rae C, Nicholson JK. 2001. Metabolic profile of gentic disorders: a multiple ${ }^{1} \mathrm{H}$ nuclear magnetic resonance spectroscopic and pattern recognition study into dystrophic tissue. Anal Biochem 293:16-21.

Griffin JL, Sang E, Evens T, Davies K, Clarke K. 2002. Metabolic profiles of dystrophin and utrophin expression in mouse models of Duchenne muscular dystrophy. FEBS Lett 530:109-116.

Haenggi T, Fritschy JM. 2006. Role of dystrophin and utrophin for assembly and function of the dystrophin glycoprotein complex in non muscle tissue. Cell Mol Life Sci 63:1614-1631.

Haenggi T, Soontornmalai A, Schaub MC, Fritschy JM. 2004. The role of utrophin and Dp71 for assembly of different dystrophin-associated protein complexes (DPCs) in the choroid plexus and microvasculature of the brain. Neuroscience 129:403-413.

Hatton GI. 1997. Function-related plasticity in hypothalamus. Annu Rev Neurosci 20:375-397.

Hernandez-Gonzalez EO, Mornet D, Rendon A, Martinez-Rojas D. 2005. Absence of Dp71 in $\mathrm{mdx} 3 \mathrm{cv}$ mouse spermatozoa alters flagellar morphology and the distribution of ion channels and nNOS. J Cell Sci 118:137-145.

Imamura M, Ozawa E. 1998. Differential expression of dystrophin isoforms and utrophin during dibutyryl-cAMP-induced morphological differentiation of rat brain astrocytes. Proc Natl Acad Sci U S A 95:61396144.

Jancsik V, Hajos F. 1999. The demonstration of immunoreactive dystrophin and its developmental expression in perivascular astrocytes. Brain Res 831:200-205.

Kim TW, Wu K, Xu JL, Black IB. 1992. Detection of dystrophin in the postsynaptic density of rat brain and deficiency in a mouse model of Duchenne muscular dystrophy. Proc Natl Acad Sci U S A 89:1164211644.

Kondo N, Arima H, Banno R, Kuwahara S, Sato I, Oiso Y. 2004. Osmoregulation of vasopressin release and gene transcription under acute and chronic hypovolemia in rats. Am J Physiol Endocrinol Metab 286:E337-E346.

Lidov HG, Byers TL, Watkins SC, Kunkel LM. 1990. Localization of dystrophin to postsynaptic regions of central nervous system cortical neurons. Nature 348:725-728.

Loufrani L, Matrougui K, Gorny D, Duriez M, Blanc I, Levy BI, Henrion D. 2001. Flow (shear stress)-induced endothelium-dependant 
dilatation is altered in mice lacking the gene encoding for dystrophin. Circulation 103:864-870.

Matsumara K, Campbell KP. 1994. Dystrophin-glycoprotein complex: its role in the molecular pathogenesis of muscular dystrophies. Muscle Nerve 17:2-15.

Matsunaga W, Miyata S, Kiyohara T. 1999. Redistribution of MAP2 immunoreactivity in the neurohypophysial astrocytes of adult rats during dehydration. Brain Res 829:7-17

McKinley MJ, Mathai ML, McAllen RM, McClear RC, Miselis RR, Pennington GL, Vivas L, Wade JD, Oldfield BJ. 2004. Vasopressin: osmotic and hormonal regulation by the lamina terminalis. J Neuroendocrinol 16:340-347.

Miller M, Moses AM. 1971. Radioimmunoassay of urinary antidiuretic hormone with application to study of the Brattleboro rat. Endocrinology 88:1389-1396.

Nico B, Frigeri A, Nicchia GP, Corsi P, Ribatti D, Quondamatteo F, Herken R, Girolamo F, Marzullo A, Svelto M, Roncali L. 2003. Severe alterations of endothelial and glial in the blood-brain barrier of dystrophic mdx mice. Glia 42:235-251.

Rae C, Griffin JL, Blair DH, Bothwell JH, Bubb WA, Maitland A, Head S. 2002. Abnormalities in brain biochemistry associated with lack of dystrophin: studies of the $m d x$ mouse. Neuromusc Disord 12:121-129.

Robert FR, Léon-Henri BP, Chapleur-Chateau MM, Girr MN, Burlet AJ. 1985. Comparison of three immunoassays in the screening and characterization of monoclonal antibodies against arginine-vasopressin. J Neuroimmunol 9:205-220.

Rosso L, Mienville JM. 2009. Pituicyte modulation of neurohormone output. Glia 57:235-243.

Royuela M, Chazalette D, Hugon G, Paniagua R, Guerlavais F, Fehrentz JA, Martinez J, Labbe JP, Rivier F, Mornet D. 2003. Formation of multiple complexes between $\beta$-dystroglycan and dystrophin family products. J Muscle Res Cell Motil 24:387-397.

Sarig R, Mezger-Lallemand V, Gitelman I, Davis C, Fuchs O, Yaffe D, Nudel U. 1999. Targeted inactivation of Dp71, the major non-muscle product of the DMD gene: differential activity of the Dp71 promoter during development. Hum Mol Genet 8:1-10.
Schofield JN, Blake DJ, Simmons C, Morris GE, Tinsley JM, Davies KE, Edwards YH. 1994. Apodystrophin-1 and apodystrophin-2, products of the Duchenne muscular dystrophy locus: expression during mouse embryogenesis and in cultured cell lines. Hum Mol Genet 3:13091316.

Sheng M, Wyszynski M. 1997. Ion channel targeting in neurons. Bioessays 19:847-853.

Shumyatcher Y, Shah TA, Noritz GH, Brouhard BH, Spirnak JP, Birnkrant DJ. 2008. Symptomatic nephrolithiasis in prolonged survivors of Duchenne muscular dystrophy. Neuromusc Disord 18:561-564.

Singh M, Jacobs IB, Spirnak JP. 2007. Nephrolithiasis in patients with Duchenne muscular dystrophy. Urology 70:643-645.

Stuhrmann M, Heilbronner $\mathrm{H}$, Reis A, Wegner RD, Fischer $\mathrm{P}$, Schmidtke J. 1991. Characterization of a Xp21 microdeletion syndrome in a 2 year-old boy with muscular dystrophy, glycerol kinase deficiency and adrenal hypoplasia congenita. Hum Genet 86:414-415.

Theodosis DT. 2002. Oxytocin-secreting neurons: a physiological model of morphological neuronal and glial plasticity in the adult hypothalamus. Front Neuroendocrinol 23:101-135.

Trembleau A, Roche D, Calas A. 1993. Combination of non-radioactive and radioactive in situ hybridization with immunohistochemistry: a new method allowing the simultaneous detection of two mRNAs and one antigen in the same brain tissue section. J Histochem Cytochem 41:489-498.

Tweedle CD, Hatton GI. 1987. Morphological adaptability at neurosecretory axonal endings on the neurovascular contact zone of the rat neurohypophysis. Neuroscience 20:241-246.

Vacher CM, Frétier P, Créminon C, Calas A, Hardin-Pouzet H. 2002. Activation by serotonin and noradrenaline of vasopressin and oxytocin expression in the mouse paraventricular and supraoptic nuclei. J Neurosc 22:1513-1522

Yanagisawa A, Yokota N, Miyagawa M, Kawamura J, Ishihara T, Aoyagi T, Ishikawa K. 1990. Plasma levels of atrial natriuretic peptide in patients with Duchenne's progressive muscular dystrophy. Am Heart J 120:1154-1158.

Zhang Z, Bourque CW. 2003. Osmosensory neurons. Nat Neurosci 6:1021-1022 